Provided for non-commercial research and education use. Not for reproduction, distribution or commercial use.

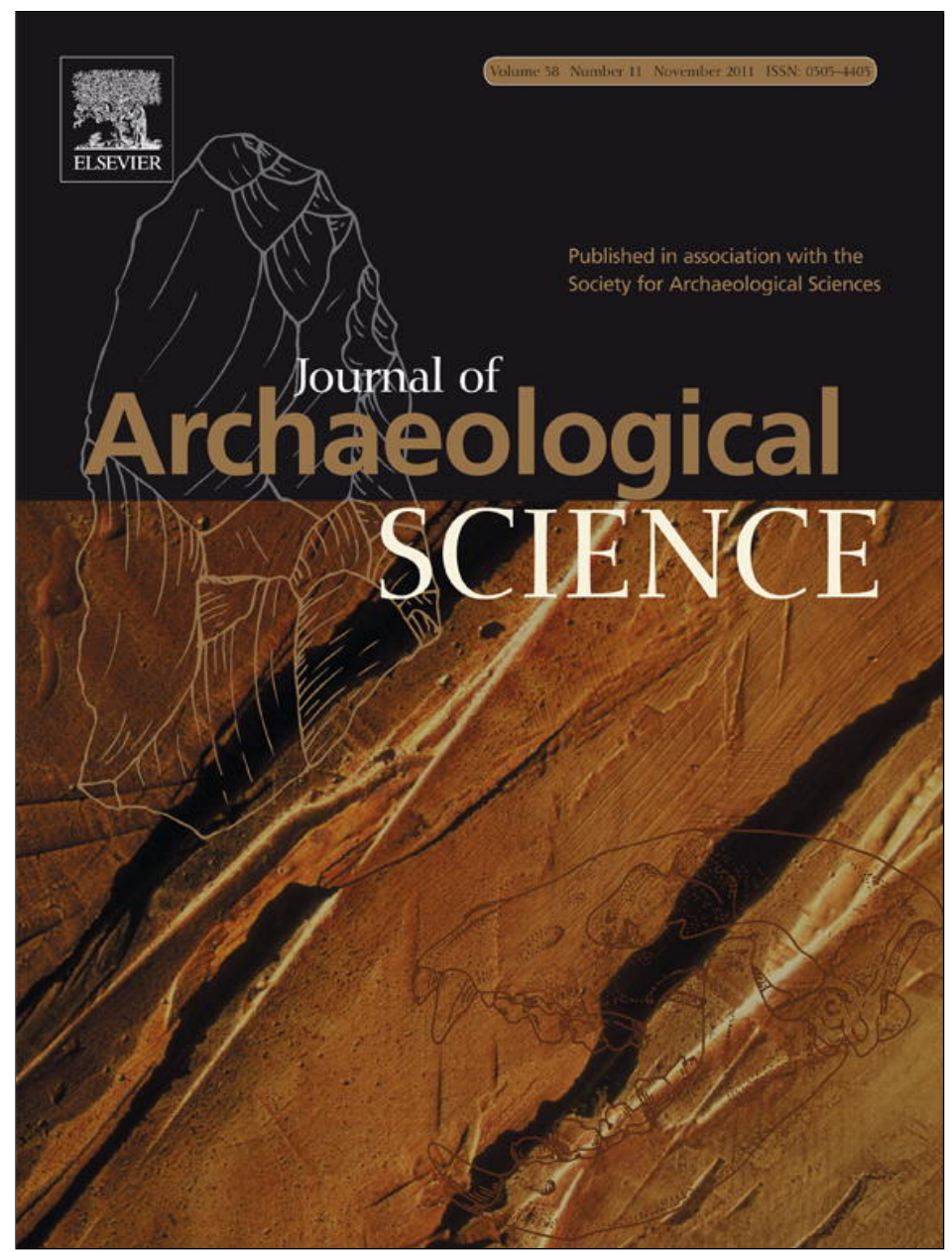

This article appeared in a journal published by Elsevier. The attached copy is furnished to the author for internal non-commercial research and education use, including for instruction at the authors institution and sharing with colleagues.

Other uses, including reproduction and distribution, or selling or licensing copies, or posting to personal, institutional or third party websites are prohibited.

In most cases authors are permitted to post their version of the article (e.g. in Word or Tex form) to their personal website or institutional repository. Authors requiring further information regarding Elsevier's archiving and manuscript policies are encouraged to visit:

http://www.elsevier.com/copyright 


\title{
Upper Palaeolithic hunter-gatherer subsistence in Mediterranean coastal environments: an isotopic study of the diets of the earliest directly-dated humans from Sicily
}

\author{
Marcello A. Mannino ${ }^{\mathrm{a}, *}$, Rosaria Di Salvo ${ }^{\mathrm{b}}$, Vittoria Schimmenti ${ }^{\mathrm{b}}$, Carolina Di Patti ${ }^{\mathrm{c}}$, \\ Alessandro Incarbona ${ }^{d}$, Luca Sineo ${ }^{e}$, Michael P. Richards ${ }^{a, f}$ \\ a Department of Human Evolution, Max Planck Institute for Evolutionary Anthropology, Deutscher Platz 6, 04103 Leipzig, Germany \\ ${ }^{\mathrm{b}}$ Museo Archeologico Regionale "Antonino Salinas", Palermo, Italy \\ "Museo Geologico "Gaetano Giorgio Gemmellaro", Università degli Studi di Palermo, Palermo, Italy \\ ${ }^{\mathrm{d}}$ Dipartimento di Geologia e Geodesia, Università degli Studi di Palermo, Palermo, Italy \\ e Dipartimento di Biologia Animale “Giuseppe Reverberi”, Università degli Studi di Palermo, Palermo, Italy \\ ${ }^{\mathrm{f}}$ Department of Anthropology, University of British Columbia, Vancouver, Canada
}

\section{A R T I C L E I N F O}

\section{Article history:}

Received 11 April 2011

Received in revised form

5 July 2011

Accepted 7 July 2011

\section{Keywords:}

Mediterranean

Late Upper Palaeolithic

Hunter-gatherers

Carbon isotope analyses

Nitrogen isotope analyses

Grotta di San Teodoro

Grotta dell'Addaura

\begin{abstract}
A B S T R A C T
The subsistence of hunter-gatherers in the Mediterranean Basin has been the object of few studies, which have not fully clarified the role of aquatic resources in their diets. Here we present the results of AMS radiocarbon dating and of isotope analyses on the earliest directly-dated human remains from Sicily, the largest island in the Mediterranean Sea. The radiocarbon determinations show that the Upper Palaeolithic (Epigravettian) humans from Grotta di San Teodoro (15 232-14 126 cal. BP) and Grotta Addaura Caprara (16 060-15 007 cal. BP) date to the Late-glacial and were possibly contemporary. The diets of these individuals were dominated by the protein of large terrestrial mammalian herbivores, such as red deer (Cervus elaphus). There is no evidence for the consumption of marine resources, which is probably the result not only of the oligotrophic nature of the Mediterranean, but also perhaps of the lack of adequate technology for exploiting intensively the resources from this sea. In spite of being contemporaneous and of the cultural and technological affinities present between the San Teodoro and Addaura humans, the carbon $\left(\delta^{13} \mathrm{C}\right)$ and nitrogen $\left(\delta^{15} \mathrm{~N}\right)$ isotope composition of their bone collagen suggests that significant differences were present in their diets. In particular, the hunter-gatherers from Grotta di San Teodoro, in NE Sicily where coastal plains are backed by high mountain chains (Monti Nebrodi), probably had easy access to resources such as anadromous brown trout (Salmo trutta), which might not have been similarly available in the NW of the island, where reliefs are noticeably lower and watercourses fewer and farther between. This study shows that the high biodiversity of this region, which results from the complex topography of Mediterranean landscapes, was probably exploited opportunistically by Lateglacial foragers. Our data also suggest that intensification and diversification of food acquisition in Sicily did not start in the closing stages of the late Pleistocene, as in other Mediterranean regions, probably because the island had only been (re-)colonized by humans around the Last Glacial Maximum. (c) 2011 Elsevier Ltd. All rights reserved.
\end{abstract}

\section{Introduction}

The antiquity of human settlement on the Mediterranean island of Sicily is still a matter of debate. Surface finds of seemingly Lower Palaeolithic stone tools have been made, as reviewed by Tusa (1999), but stratified evidence for human presence is only

\footnotetext{
* Corresponding author.

E-mail address: marcello.mannino@eva.mpg.de (M.A. Mannino).
}

available from the Upper Palaeolithic. The chronological attribution of Riparo di Fontana Nuova to the Aurignacian (Chilardi et al., 1996), based as it is solely on the typology of its lithic industry, has been questioned by Martini et al. (2007). No mid-Upper Palaeolithic (Gravettian) site has been discovered in Sicily, while recent excavations at late Upper Palaeolithic sites (Martini et al., 2007) and studies on museum collections from them (Mannino and Thomas, 2007) have confirmed that humans were certainly present on the island by the Late-glacial, during the cultural phase of the Late or Final Epigravettian. 
The Late Epigravettian humans of Sicily left substantial traces of their presence in the form of lithics, food refuse and rock art (Tusa, 1999). Archaeozoological studies show that these hunter-gatherers hunted large terrestrial mammals (as reviewed by Martini et al., 2007), such as red deer (Cervus elaphus), aurochs (Bos primigenius), hydruntine ass (Equus hydruntinus), wild boar (Sus scrofa) and fox (Vulpes vulpes). Intertidal marine molluscs were consumed at coastal sites (Martini et al., 2007; Mannino and Thomas, 2007, 2009), bird hunting was practiced (Cassoli and Tagliacozzo, 1982), while fishing was rare until the early Holocene (Tagliacozzo, 1993). Archaeozoological evidence suggests that Epigravettian foragers in Sicily ate a relatively small range of foods compared to coeval hunter-gatherers in southern Italy. Faunal assemblages from Late Epigravettian sites, such as Grotta Romanelli in Apulia (Cassoli and Tagliacozzo, 1997; Tagliacozzo, 2003) and Grotta della Madonna di Praia a Mare in Calabria (Durante, 1978; Fiore et al., 2004), attest that subsistence was based on the hunting of large terrestrial herbivores and on the exploitation of small mammals (e.g. lagomorphs), birds, fish and molluscs.

Remains of Upper Palaeolithic humans have been recovered in northern Sicily at the sites of Grotta d'Oriente (Martini et al., 2007), Grotta di San Teodoro (Graziosi, 1947) and Grotta Addaura Caprara (this paper). We undertook carbon and nitrogen isotope analyses on collagen extracted from human bones from the San Teodoro and Addaura caves to acquire direct data on the diets of Late Epigravettian hunter-gatherers in Sicily. Carbon isotopes are useful to determine the contribution of marine versus terrestrial protein in human diets (Lee-Thorp, 2008). Nitrogen isotopes are indicators of the trophic level of the protein consumed, given that mammal bone collagen values are enriched compared to those of their dietary protein by $2-4 \%$ according to some studies (e.g. Schoeninger and DeNiro, 1984) or $3-5 \%$ according to others (e.g. Bocherens and Drucker, 2003). Isotope analyses on the remains of Late Epigravettian hunter-gatherers allow us to test whether reconstructions of their diets based on the faunal food refuse from the cave sites they occupied provide us with a complete picture, in which case one could also conclude that the archaeological record is representative of the original range of occupied sites. However, a lack of concordance between palaeodietary reconstructions based on the faunal remains and those arising from the isotope analyses would also be informative. For instance, it could indicate that not all resources were taken back for consumption at caves, possibly because these kinds of sites were not occupied year round (Mannino et al., in press).

\section{Grotta di San Teodoro}

Grotta di San Teodoro is a cave in NE Sicily, situated between the cities of Palermo and Messina (Fig. 1). The cave opens on the northern reaches of the Nebrodi mountain range and is about $2 \mathrm{~km}$ south of the present-day shoreline. Excavations at the cave started in 1859, while in 1937 G. Bonafede unearthed a burial (San Teodoro 1) at a depth of $2 \mathrm{~m}$, below an ochre-rich lens (Maviglia, 1940). At the same level, Maviglia recovered human bones of five individuals, including two crania (San Teodoro 2 and 7). The first systematic excavations at the site took place in 1942, under the direction of Paolo Graziosi (1947), with the aim to investigate the stratigraphy of the deposit. Six layers were identified, the first five of which

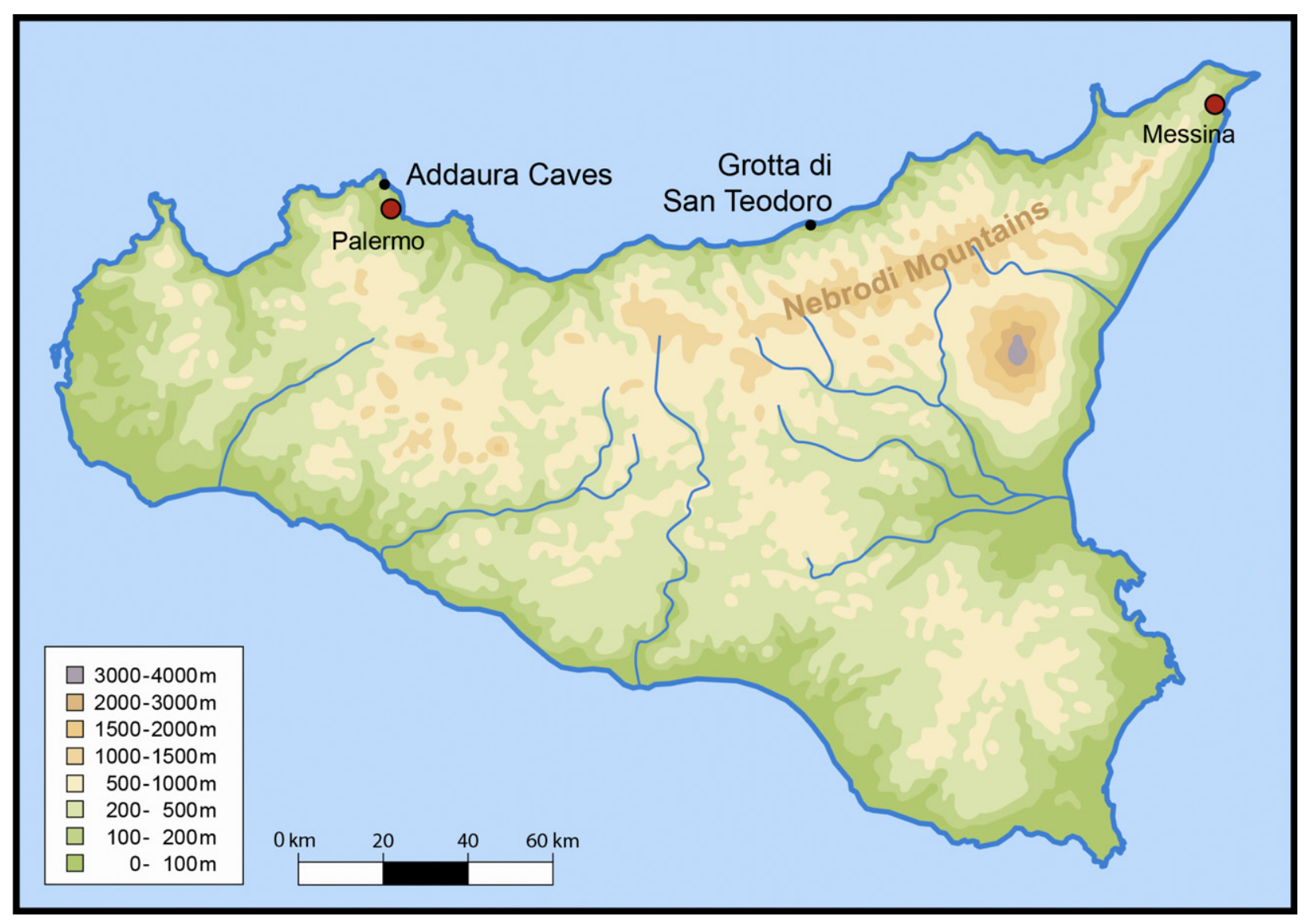

Fig. 1. Map of Sicily with location of the Addaura and San Teodoro cave sites. Note the numerous valleys present on the northern slopes of the Nebrodi Mountains (Monti Nebrodi). 
(A-E) are associated with humans. Layer C corresponds to the period of most intense occupation and contained lithics of Late Epigravettian culture (Vigliardi, 1968). The faunal assemblage was dominated by red deer, throughout the sequence, followed by wild boar (Graziosi, 1947; Martini et al., 2007). Aurochs and fox were represented by a few remains, with the former being absent from the top layers (A, B). A small surviving baulk of Layer C, excavated in 1998 (Mangano, 2005), yielded remains of red deer (76\% NISP), wild boar $(23 \%)$, fox $(1 \%)$ and aurochs $(<1 \%)$. At the bottom of layer D, there was the lens of ochre, which, as mentioned above, overlaid the Upper Palaeolithic burials (Layer E). The lowermost layer (F) did not contain traces of human occupation, but bones of Pleistocene mammals, including elephant (Elephas mnaidriensis) and hyena (Crocuta spelaea).

The faunal remains recovered by Maviglia in the Upper Palaeolithic deposits of Grotta di San Teodoro, stored at the Museo di Storia Naturale in Milan, include a few shells of marine molluscs, such as intertidal limpets (Patella ferruginea, Patella caerulea) and cockles (Cerastoderma glaucum). These molluscs are intact, and it is therefore unlikely that they were taken back to the site by animals, such as seabirds, which leave diagnostic taphonomic signatures on shells (Zuschin et al., 2003). The most likely agent responsible for the introduction of these sub-fossil molluscs were humans, who might have taken them back to the cave for consumption, as at contemporary sites in Sicily and southern Italy (Colonese et al., 2011). Independently of the agent responsible for the introduction of the cockle shells, their presence indicates that lagoons probably existed in the vicinity of the cave, when at the lower sea levels of the Late-glacial the shore would have been around 7.0-8.0 km away (these figures have been estimated using the sea level curve published by Lambeck et al., 2004). No information exists on the presence of fish bones and so it is not known whether the occupants of the cave practiced fishing.

Grotta di San Teodoro contained the remains of seven prehistoric humans, six of which (i.e. San Teodoro 1-4 and 6-7) have been attributed to the Upper Palaeolithic (D'Amore et al., 2009). All the individuals are adults, three being female (San Teodoro 1, 4 and 6) and four male (San Teodoro 2, 3, 5 and 7). The craniofacial morphology of the San Teodoro individuals is typical of Upper Palaeolithic West European modern humans and their morphometric characters are most similar to those of coeval humans from southern Italy (D'Amore et al., 2009). It has, therefore, been hypothesized that the San Teodoro individuals descended from modern humans who migrated to Sicily from Italy at some stage after the Last Glacial Maximum. Dental microwear suggests that the diet of the San Teodoro individuals was rich in plant foods, while trace element analyses indicate that it was meat-based. Carnieri and Mallegni (2006) interpret this seemingly contradictory evidence as indicating a mixed, well-balanced diet.

\section{The Addaura caves}

A complex of five caves is present on the northern slopes of Monte Pellegrino at a locality known as Addaura (Fig. 1), close to the modern city of Palermo. Three of the caves have been excavated (Grotta Addaura Caprara, Grotta dei Bovidi and Grotta delle Incisioni), although rarely in a systematic fashion. The methodologically most reliable excavations took place in 1946-47 under the direction of Jole Bovio Marconi, in collaboration with Luigi Bernabò Brea. The lithics recovered indicate that the Addaura caves were occupied by Upper Palaeolithic and Mesolithic hunter-gatherers (Bovio Marconi, 1946). AMS radiocarbon dating has confirmed this chronological attribution, assigning the deposits to the Late Epigravettian, the last cultural phase of the Upper Palaeolithic (Mannino and Thomas, 2007). The most notable feature of the
Addaura caves is the rock art discovered at Grotta delle Incisioni, a unique example of prehistoric engravings featuring human and animal figures (Tusa, 1999). The economy of the Addaura huntergatherers was based on hunting of large herbivores (especially red deer), shellfish exploitation and, possibly, bird hunting (Mannino and Thomas, 2009).

Human bones from Grotta Addaura Caprara have been 'rediscovered' by the main author (M.A.M.) among collections of the Museo Geologico "G.G. Gemmellaro", which were recently moved to the Museo Archeologico Regionale "A. Salinas" in Palermo. These include bones that were found at the cave in 1916 by an amateur named Scaturro. The 'Scaturro collection' includes a total of six human bones (a right scapula, a left ulna, a left ilium, a right ilium, a left fibula and a fragmentary tibia). The scapula, ulna, ilia and fibula probably all belong to a single individual (Addaura 1), an adult female, based on the morphology of the ilia. This attribution is supported by the similar state of preservation of the bones and by the same colour of deposit encrusting them, which suggests that they might originate from a burial.

\section{Materials and methods}

In the past, human remains from excavations in Italy were sent to physical anthropologists at institutions across the country, which resulted in the fragmentation of the collections. We were only able to sample the bones of San Teodoro 1 and 2, stored at the Museo Geologico "G.G. Gemmellaro" (Palermo), and San Teodoro 7, at the Museo di Storia Naturale in Milan. The left humerus of San Teodoro 1 and two cranial fragments from San Teodoro 2 were sampled for AMS radiocarbon dating, while all three San Teodoro specimens were sampled for carbon and nitrogen isotope analyses. Upper Palaeolithic animal bones recovered by Maviglia at Grotta di San Teodoro (stored at the Museo di Storia Naturale in Milan) were analysed to establish the isotopic baseline of the area around the cave, in order to interpret the human isotope data. Of the bones from the 'Scaturro collection', the human fibula (Addaura 1) was sampled for dating and isotope analyses. A representative sample of the few animal bones in the collections from Grotta delle Incisioni, one of the Addaura caves with Late Epigravettian deposits (Mannino and Thomas, 2007), was also taken for analysis.

The collagen extraction was performed following protocols proposed by Brown et al. (1988) and modified by Richards and Hedges (1999). Collagen samples were run in duplicates at the Max Planck Institute for Evolutionary Anthropology (Leipzig, Germany) on a ThermoFinnigan Flash EA coupled to a Delta Plus XP isotope ratio monitoring mass spectrometer. The $\delta^{13} \mathrm{C}$ values are reported relative to the V-PDB standard and the $\delta^{15} \mathrm{~N}$ values are reported relative to the AIR standard. The analytical precision of the carbon and nitrogen isotope analyses based on repeated measurements was better than $0.20 \%$.

The sampled human bones yielded sufficient collagen for analysis. The extracts have yields, $\mathrm{C} / \mathrm{N}$ ratios, \% $\mathrm{C}$ and \% $\mathrm{N}$ contents (Tables 2 and 3), which taken together are compatible with wellpreserved collagen (van Klinken, 1999) in the case of San Teodoro 1 (S-EVA 2829), the smallest sample from San Teodoro 2 (S-EVA 2827), San Teodoro 7 (S-EVA 14777) and Addaura 1 (S-EVA 2821). The largest of the cranial fragments from San Teodoro 2 (S-EVA 2828 ) yielded an extract with a $\mathrm{C} / \mathrm{N}$ ratio of 3.9 , which is above the range for collagen. All the animal bone samples yielded sufficient collagen for isotope analyses (Tables 2 and 3), with the exception of three specimens (S-EVA 13789, 13794, 14781). Faunal samples have weight percentages higher than $0.8 \%, \mathrm{C} / \mathrm{N}$ ratios, \%C and $\% \mathrm{~N}$ contents which meet quality criteria for well-preserved collagen (van Klinken, 1999). 
Table 1

AMS radiocarbon dates on bone collagen extracted from Upper Palaeolithic (Late Epigravettian) human remains from Grotta di San Teodoro and Grotta Addaura Caprara. Collagen was extracted and prepared for dating according to the procedures of the Oxford Radiocarbon Accelerator Unit. The dates were calibrated with Oxcal 4.1. (Bronk Ramsey, 2009) using the IntCal09 calibration curve (Reimer et al., 2009).

\begin{tabular}{|c|c|c|c|c|c|}
\hline $\begin{array}{l}\text { Max Planck } \\
\text { Institute lab. no. S-EVA }\end{array}$ & $\begin{array}{l}\text { Radiocarbon } \\
\text { laboratory number }\end{array}$ & Individual & $\begin{array}{l}\text { Conventional } \\
\text { radiocarbon age (BP) }\end{array}$ & ‘Calendar age’ cal. BC $(2 \sigma)$ & 'Calendar age' cal. BP $(2 \sigma)$ \\
\hline 2829 & ETH-34451 & San Teodoro 1 & $12580 \pm 130$ & $13283(95.4 \%) 12177$ & $15232(95.4 \%) 14126$ \\
\hline 2821 & KIA-36055 & Addaura 1 & $12890 \pm 60$ & $\begin{array}{l}14111(1.5 \%) 14036 \\
14001(93.9 \%) 13058\end{array}$ & $\begin{array}{l}16060(1.5 \%) 15985 \\
15950(93.9 \%) 15007\end{array}$ \\
\hline
\end{tabular}

\section{Results}

The AMS radiocarbon date confirms that San Teodoro 1 (15 232-14 126 cal. BP) is Late Epigravettian (Table 1), in accord with the attribution based on the lithic typology (Vigliardi, 1968). Similarly, the date on Addaura 1 (Table 1) indicates that this individual (including all the bones of the 'Scaturro collection' except the tibia) is Late Epigravettian (16 060-15 007 cal. BP). San Teodoro 1 and Addaura 1 might be either contemporary, given the overlap in the $2 \sigma$ ranges of their calibrated ages, or the latter individual might be slightly older, implying that it is the most ancient directly-dated human from Sicily.

The isotope values for the terrestrial herbivores (Tables 2 and 3; Fig. 2) are characteristic of animals feeding on plants with a $C_{3}$ photosynthetic pathway, as expected of past Mediterranean environments (Tzedakis, 2009), and are very consistent between the two sites (Addaura: $\delta^{13} \mathrm{C}$ mean $=-20.7 \pm 0.4 \%$ and $\delta^{15} \mathrm{~N}$ mean $=6.8 \pm 0.8 \%$; San Teodoro: $\delta^{13} \mathrm{C}$ mean $=-21.3 \pm 0.3 \%$ and $\delta^{15} \mathrm{~N}$ mean $=6.5 \pm 0.9 \%$ ). The wild boar from Addaura has intermediate isotopic values between herbivores and carnivores, in the norm for omnivores, while the San Teodoro boars have values similar to herbivores, implying that their dietary protein came mainly from plants. The fox from Addaura has values compatible with an opportunistic carnivore, while the $\delta^{15} \mathrm{~N}$ value for the wolf is consistent with a top level carnivore, as it is around $3.0 \%$ higher than the herbivore mean.

The $\delta^{13} \mathrm{C}$ value for the human specimen Addaura 1 is $1.0 \%$ higher than the average value for the herbivores, while the $\delta^{15} \mathrm{~N}$ value is around $3.0 \%$ higher than the herbivore mean. These offsets, and the fact that this human has a similar isotopic composition to the wolf, imply that the dietary protein of Addaura 1 originated from the meat of terrestrial herbivores. The $\delta^{15} \mathrm{~N}$ value of Addaura 1 is barely $1.0 \%$ higher than the $\delta^{15} \mathrm{~N}$ values of wild boar and fox, thereby indicating that the meat of these animals would have been rarely consumed. The $\delta^{13} \mathrm{C}$ and $\delta{ }^{15} \mathrm{~N}$ values of Addaura 1 are consistent with high consumption of herbivore meat and, particularly, of red deer. Different combinations of foodstuffs, as for example aurochs meat plus plant food protein, could in theory also account for the data, but these possibilities can be discarded because aurochs is rare in late Upper Palaeolithic faunal assemblages from Sicily (including those from the Addaura caves) and red deer overwhelmingly dominates practically all assemblages (Martini et al., 2007).

San Teodoro 1 and 2 have $\delta^{13} \mathrm{C}$ values enriched by $1.3 \%$ compared to the herbivores and $\delta^{15} \mathrm{~N}$ values respectively $5.5 \%$ and $5.0 \%$ higher than the herbivore mean for the site. The $\delta^{15} \mathrm{~N}$ ratios are above a trophic level shift expected between a consumer and its prey, even if we consider the widest estimation for this (i.e. $3-5 \%$; Bocherens and Drucker, 2003). A considerable proportion of the protein consumed by these humans, hence, did not come from red deer or wild boar, which as mentioned above are the most abundant mammals in the assemblage (Mangano, 2005). Two possible explanations can account for this data: (a) the main source of dietary protein was aurochs, or (b) a significant proportion of protein might have originated from aquatic resources (up to around a fifth for San Teodoro 1), such as fish or birds, which have higher $\delta^{15} \mathrm{~N}$ values than terrestrial fauna (Richards et al., 2001). San Teodoro 7 has a slightly lower $\delta^{15} \mathrm{~N}$ value $(11.5 \%)$ relative to the other humans from the same cave, but its $\delta^{13} \mathrm{C}$ value is considerably higher (ca. $2.0 \%$ ) than the mean for the herbivores, which could also be explained by the consumption of some protein from aquatic (fresh or brackish water) resources, in an otherwise terrestrial diet.

Regarding 'hypothesis a', it should be noted that mean $\delta^{15} \mathrm{~N}$ ratios for aurochs were probably lower than the $8.2 \%$ value recorded on the single specimen analysed from San Teodoro, given that the mean $\delta^{15} \mathrm{~N}$ value for the Addaura specimens is $7.0 \%$ and that individuals of the same species analysed from contemporary Late-glacial sites in southern Italy have yielded mean $\delta^{15} \mathrm{~N}$ values also around 7.0\% (Iacumin et al., 1997; Craig et al., 2010). It is, therefore, unlikely that San Teodoro 1 and 2 consumed mainly aurochs, because only the almost exclusive consumption of this species could justify the $\delta^{15} \mathrm{~N}$ values for San Teodoro 2, while not even fully exclusive consumption could have produced the shift recorded for San Teodoro 1.

Table 2

Carbon and nitrogen isotope values of bone collagen of Upper Palaeolithic (Late Epigravettian) humans (San Teodoro 1, 2 and 7) and fauna from Grotta di San Teodoro. The values of extracts which are not assignable to well-preserved collagen are shown in italics. (coll. = collagen).

\begin{tabular}{|c|c|c|c|c|c|c|c|c|}
\hline MPI lab. N. (S-EVA) & Species & Bone & $\delta^{13} \mathrm{C}(\%)$ & $\delta^{15} \mathrm{~N}(\%)$ & $\% \mathrm{C}$ & $\% \mathrm{~N}$ & $\mathrm{C} / \mathrm{N}$ & $\%$ coll. \\
\hline 2829 & Homo sapiens (San Teodoro 1) & Humerus & -20.0 & 12.5 & 39.2 & 13.0 & 3.5 & 0.9 \\
\hline 2827 & Homo sapiens (San Teodoro 2) & Cranium & -20.0 & 12.0 & 42.0 & 13.5 & 3.6 & 0.5 \\
\hline 2828 & Homo sapiens (San Teodoro 2) & Cranium & -20.2 & 11.4 & 45.3 & 13.5 & 3.9 & 0.9 \\
\hline 14777 & Homo sapiens (San Teodoro 7) & Cranium & -19.1 & 11.5 & 42.8 & 15.0 & 3.3 & 9.0 \\
\hline 14785 & Bos primigenius & Long bone & -21.5 & 8.2 & 43.3 & 14.6 & 3.5 & 3.1 \\
\hline 14781 & Bos primigenius & Cranium & - & - & - & - & - & 0.1 \\
\hline 14779 & Cervus elaphus & Metatarsus & -20.9 & 6.2 & 42.5 & 14.9 & 3.3 & 2.7 \\
\hline 14780 & Cervus elaphus & Hamate & -21.1 & 6.1 & 41.4 & 14.2 & 3.4 & 2.5 \\
\hline 14783 & Cervus elaphus & Rib & -21.8 & 5.3 & 31.5 & 10.6 & 3.5 & 1.9 \\
\hline 14778 & Sus scrofa & Maxilla & -21.2 & 6.2 & 32.5 & 11.0 & 3.5 & 2.8 \\
\hline 14784 & Sus scrofa & Phalanx II & -21.3 & 6.2 & 42.0 & 14.4 & 3.4 & 0.8 \\
\hline 14782 & Equus hydruntinus & Mandible & -24.0 & 6.1 & 37.1 & 6.8 & 6.3 & 2.0 \\
\hline
\end{tabular}


Table 3

Carbon and nitrogen isotope values of bone collagen of the Upper Palaeolithic (Late Epigravettian) human from Grotta Addaura Caprara and of contemporary fauna recovered in Trench III at the nearby Grotta delle Incisioni (for details see Mannino and Thomas, 2007).

\begin{tabular}{|c|c|c|c|c|c|c|c|c|c|}
\hline MPI lab. N. (S-EVA) & Context & Species & Bone & $\delta^{13} \mathrm{C}(\%)$ & $\delta^{15} \mathrm{~N}(\%)$ & $\% \mathrm{C}$ & $\% \mathrm{~N}$ & $\mathrm{C} / \mathrm{N}$ & $\%$ coll. \\
\hline 2821 & Addaura 1 & Homo sapiens & Fibula & -19.7 & 9.6 & 44.1 & 15.4 & 3.3 & 4.3 \\
\hline 13792 & Spit 1bis & Vulpes vulpes & Metapodial & -19.2 & 8.3 & 41.6 & 14.6 & 3.3 & 1.8 \\
\hline 13795 & Spit 2bis & Canis lupus & Metapodial & -20.4 & 9.9 & 42.4 & 15.0 & 3.3 & 2.4 \\
\hline 13791 & Spit 1bis & Bos primigenius & Rib & -20.1 & 8.3 & 41.5 & 13.9 & 3.5 & 1.5 \\
\hline 13793 & Spit 2bis & Bos primigenius & Metatarsus & -20.4 & 5.7 & 42.3 & 14.8 & 3.3 & 3.4 \\
\hline 13794 & Spit 1 bis & Cervus elaphus & Metatarsus & - & - & - & - & - & 0 \\
\hline 13796 & Spit 1 bis & Cervus elaphus & Mandible & -20.9 & 6.3 & 41.9 & 14.3 & 3.4 & 4.7 \\
\hline 13797 & Spit 1bis & Cervus elaphus & Metacarpus & -21.2 & 6.4 & 41.7 & 14.2 & 3.4 & 3.5 \\
\hline 13790 & Spit 1bis & Sus scrofa & Mandible & -20.3 & 8.5 & 41.3 & 14.4 & 3.4 & 1.9 \\
\hline 13789 & Spit 1bis & Equus hydruntinus & Metapodial & - & - & - & - & - & 0 \\
\hline
\end{tabular}

To ascertain whether 'hypothesis b' is a plausible interpretation of the isotope data it is necessary to take into account data from other sites, given the absence of aquatic fauna at Grotta di San Teodoro. For this purpose, due to the lack of published data on Mediterranean fauna, we report preliminary unpublished results of analyses on brown trout (Salmo trutta) from the Late-glacial deposits of Grotta Continenza, a cave in central Italy where thousands of bones of this species were recovered. This species is still present in the Mediterranean Basin today, but only in freshwater habitats, while during the Late-glacial it was also anadromous (i.e. some of its populations lived in the sea and migrated up watercourses to reproduce), as sea surface temperatures were lower (Durante, 1978). Samples of well-preserved collagen extracted from thirty-five brown trout bones, recovered at Grotta Continenza, have isotopic compositions ranging from $-20.0 \%$ to $-14.0 \%$ for $\delta^{13} \mathrm{C}$ (mean $=-17.2 \%$ ) and from $9.0 \%$ to $13.0 \%$ for $\delta^{15} \mathrm{~N}$ (mean $=11.1 \%$ ). These data confirm that the acquisition of dietary protein from the flesh of anadromous fish, such as brown trout, would have produced mainly an increase in the $\delta^{15} \mathrm{~N}$ values of the bone collagen of the consumer. This could, thus, account for the $\delta^{15} \mathrm{~N}$ values of all three Upper Palaeolithic humans from Grotta di San Teodoro, as well as for the variability in their isotopic composition. The slightly higher $\delta^{13} \mathrm{C}$ values registered for San Teodoro 7 could, however, also be explained by consumption of marine species which periodically occur in brackish water environments. In fact, the consumption of fully marine fish and mammals can be excluded on the basis of the limited isotope data available in the literature for prehistoric specimens, which suggest that these taxa have $\delta^{13} \mathrm{C}$ values significantly higher than terrestrial and freshwater

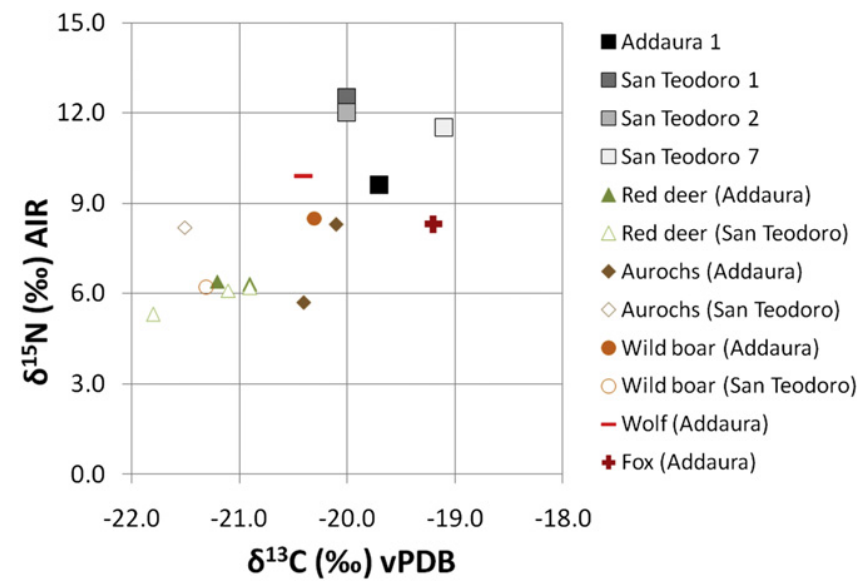

Fig. 2. Carbon and nitrogen isotope composition of the bone collagen from the Upper Palaeolithic (Late Epigravettian) humans and fauna of the Addaura and San Teodoro caves. fauna (Francalacci, 1988; Garcia-Guixé et al., 2010; Lightfoot et al., 2011). On the other hand, judging by analyses on tissues of modern marine fauna (e.g. Jennings et al., 1997; Persic et al., 2004), which might not be directly comparable with those on bone collagen samples from prehistoric specimens (Garcia-Guixé et al., 2010), it appears that the $\delta^{13} \mathrm{C}$ composition of some coastal species that regularly enter brackish water habitats, such as lagoons, overlaps marginally with that of freshwater taxa. Consequently, it is possible that the higher $\delta^{13} \mathrm{C}$ value of the bone collagen from San Teodoro 7 is indicative of the consumption by this individual of marine species that also occur in lagoons, which as attested by the Cerastoderma specimens presented in this study were present in the vicinity of Grotta di San Teodoro. We can, therefore, conclude that the isotope data from the San Teodoro humans indicate a varied diet enriched in protein from aquatic resources, such as molluscs, fish and/or birds (see Richards et al., 2001).

\section{Discussion}

The radiocarbon dates on the humans from the Addaura and San Teodoro caves place these two individuals in the Late-glacial period and, more specifically, between the end of the Oldest Dryas and the beginning of the Bølling-Allerød interstadial (Ravazzi, 2003). At that time, with deglaciation, climatic conditions improved, becoming warmer and wetter, and favouring an increase in wooded as opposed to open steppe environments (Incarbona et al., 2010).

The results of the isotope analyses prove that the Late Epigravettian hunter-gatherer from Addaura consumed high levels of protein originating mainly from red deer. This is in line with the subsistence reconstructions based on the faunal remains from Upper Palaeolithic sites in Sicily (e.g. Cassoli and Tagliacozzo, 1982; Mangano, 2005; Martini et al., 2007; Mannino and Thomas, 2010), which show that red deer was generally the most hunted animal, followed by other large herbivores. The isotope data show that marine foods were rarely, if ever, consumed, with shellfish constituting a minor resource. This is congruent with data on the periodicity of shellfish collection at the Addaura caves, according to which molluscs were a highly seasonal resource, exploited only in the coolest months of the year during the closing stages of the Lateglacial (Mannino and Thomas, 2009; Mannino et al., in press).

The diet of the San Teodoro hunter-gatherers comprised a wider range of foodstuffs and was probably not centred on red deer meat as much as that of the individual from Addaura. In fact, the isotope data from the San Teodoro humans are more difficult to reconcile with the faunal evidence. The hypothesis according to which the diet of these humans was dominated by the consumption of aurochs meat, with red deer being a minor food item, is the opposite to dietary interpretations from the archaeozoological studies (Mangano, 2005). The low number of aurochs bones in 
Sicilian assemblages (e.g. Martini et al., 2007) probably reflects the low densities at which this mammal was present in Sicily, where small population size is likely to have been one of the main factors contributing to its extirpation in the early Holocene (Tagliacozzo, 1993).

On archaeozoological grounds it is, therefore, unlikely that aurochs was the main species exploited. The faunal evidence for a diet based on aquatic, as well as terrestrial, protein is even more elusive, although this might be partly due to the quality of the excavations at the cave. The most credible interpretation of the isotope data is that the San Teodoro humans consumed aquatic foods, as hypothesized for an Epigravettian hunter-gatherer from Grotta del Romito in Calabria (Craig et al., 2010) with a similar $\delta^{15} \mathrm{~N}$ value $(12.4 \%$ o $)$. This interpretation is strengthened by comparing the difference in $\delta^{15} \mathrm{~N}$ values $(2.9 \%$ ) between the contemporary humans Addaura 1 and San Teodoro 1, which essentially equates to a trophic level shift and can only be explained by inclusion in the diet of the latter of protein from aquatic (fresh or brackish water) ecosystems.

How can such a difference in the diets of groups of huntergatherers living just over $100 \mathrm{~km}$ apart be accounted for? The explanation probably lies in the different topography and, consequently, hydrology of the two areas (Fig. 1). NE Sicily is characterized by mountain chains running parallel to the shore, with many peaks above $1500 \mathrm{~m}$, which include the Nebrodi range near Grotta di San Teodoro. Precipitation in these mountains is very high (at present around $1400 \mathrm{~mm} / \mathrm{year}$ ) and water draining from them feeds numerous streams and rivers (locally called fiumare). Snow cover on high reliefs was certainly more regular and prolonged during the Late-glacial and glaciated areas might even have been present at that time in the Nebrodi mountains (Hughes and Woodward, 2009; p. 365, fig. 12.10). As a result of this, fiumare which are now dry in spring and summer could probably have had water practically all year round (sensu Macklin et al., 1995). Similar conditions to these were present in northern Calabria (SE Italy), where the hunter-gatherers of Grotta della Madonna intensively exploited brown trout, probably catching it near the mouth of the river Noce, during its migration (Durante, 1978). It can be concluded that the exploitation of brown trout by the San Teodoro huntergatherers was indeed possible from an environmental point of view. In NW Sicily (including the area around Addaura), on the other hand, reliefs are mainly below $1000 \mathrm{~m}$, precipitation is noticeably lower and there are fewer watercourses and, hence, few habitats suitable for the exploitation of non-marine aquatic resources. These observations suggest that, in Sicily, Epigravettian humans exploited aquatic resources opportunistically (e.g. during migrations up or downstream), based on what was available and easy to obtain within their territories. It could, thus, be inferred that the difference in the diets of the Addaura and San Teodoro humans implies that their territories did not overlap. Further evidence for this comes from a study of the territoriality of the hunter-gatherers that lived in and around the Conca d'Oro plain, including the group that occupied the Addaura caves (Mannino et al., in press). This study shows that hunter-gatherer territories extended as much inland, perpendicularly to the coast, as they did parallel to it. It is, therefore, almost certain that the territories of the occupants of the Addaura and San Teodoro caves did not overlap.

The limited isotopic data currently available on the bone collagen of marine Mediterranean fish indicate that, in spite of the variability observed in their $\delta^{13} \mathrm{C}$ ratios, their isotopic compositions are typically marine (e.g. Francalacci, 1988; Garcia-Guixé et al., 2010). In the light of these observations it can, hence, be concluded that the isotope analyses presented here prove that the Late Epigravettian coastal hunter-gatherers of Sicily consumed little or no protein originating from marine resources, similarly to what has emerged from analyses on contemporary humans from Arene Candide (Francalacci, 1988) and Grotta del Romito (Craig et al., 2010).

The marginal role of marine foods in the diets of Late Epigravettians is, on the one hand, a consequence of the low primary productivity and biomass of Mediterranean coastal habitats (Craig et al., 2010) compared to oceanic regions where humans were capable of surviving almost exclusively on these resources (Richards and Hedges, 1999), and, on the other hand, a result of an inadequate technology for a regular exploitation of marine fish, which in Sicily started only in the Mesolithic (Tagliacozzo, 1993). Fish in small watercourses can be caught without sophisticated fishing technology (e.g. damming streams to 'force' the fish out of water) and as a result fish, such as brown trout, were intensively exploited at Late Epigravettian sites in central (Russ and Jones, 2009) and southern Italy (Durante, 1978), from where Sicilian hunter-gatherers originated (D'Amore et al., 2009).

\section{Conclusions}

Archaeozoological (Stiner, 2001) and isotopic (Richards and Trinkaus, 2009; Richards et al., 2001) evidence from across Europe suggests that from the mid-Upper Palaeolithic onwards, a widening in the subsistence base occurred, possibly as a consequence of a demographic increase. The archaeozoological evidence available for Sicily (e.g. Cassoli and Tagliacozzo, 1982; Mangano, 2005; Martini et al., 2007; Mannino and Thomas, 2010) indicates that the broadening in the subsistence base during the late Upper Palaeolithic was not as wide-ranging or diffuse as in other Mediterranean regions (e.g. Stiner and Munro, 2011), even though, as shown in this study, aquatic resources (the remains of which are not present in the faunal assemblages) were actually consumed by some groups of hunter-gatherers living on the island. In southern Italy, for instance, a significant widening in the dietary breadth took place at many Late-glacial sites (Wilkens, 1993; Cassoli and Tagliacozzo, 1997; Tagliacozzo, 2003; Fiore et al., 2004), through the inclusion of small fast-moving vertebrates (mammals, birds and fish) from terrestrial, marine and brackish water environments. This trend, however, was very weak or even absent in Sicily.

Does this imply a less marked population increase during the late Upper Palaeolithic on the island or does it reflect inadequate technology for catching fast-moving small animals? Both hypotheses might be true, the former because there is no sign of sustained intensification and diversification of resource acquisition in Sicily prior to the late Mesolithic (Tagliacozzo, 1993), the latter because humans probably moved to the island before they had significantly broadened their subsistence base on the mainland. The second scenario implies that not all hunter-gatherers across the Mediterranean Basin modified their subsistence practices simultaneously, which could explain some of the differences observed by Martini et al. (2007) between the lithic industries of terminal Late-glacial and early Holocene Sicily and those of the Italian peninsula. The difference in the spectrum of resources exploited at southern Italian and Sicilian sites could reflect the timing of occupation of the largest island in the Mediterranean, on which the human carrying capacity of its habitats had not been reached by the Late-glacial. This adds further support to the hypothesis that Sicily was (re-) colonized late in the terminal Pleistocene, when its environments had long, if ever, been subject to anthropogenic pressures.

\section{Acknowledgements}

The authors thank Agata Villa (Museo Archeologico Regionale “A. Salinas”, Palermo), Antonio Tagliacozzo (Museo Nazionale Preistorico ed Etnografico "L. Pigorini", Rome), Renata Grifoni 
Cremonesi (Università di Pisa), Anna Alessandrello and Giulio Calegari (Museo di Storia Naturale, Milano), and last but not least Giovanni Mannino. We are also indebted to the Max Planck Society and Prof. Jean-Jacques Hublin. This research was supported by the Max Planck Society and by a Marie Curie Intra-European Fellowship within the 7th European Community Framework Programme, grant number PIEF-GA-2008-219965, awarded to M.A.M.

\section{References}

Bocherens, H., Drucker, D., 2003. Trophic level isotopic enrichment of carbon an nitrogen in bone collagen: case studies from recent and ancient terrestrial ecosystems. International Journal of Osteoarchaeology 13, 46-53.

Bovio Marconi, J., 1946. Relazione preliminare sugli scavi delle Grotte dell'Addaura. Notizie degli Scavi di Antichità (Series VII) 5-6, 160-167.

Bronk Ramsey, C., 2009. Bayesian analysis of radiocarbon dates. Radiocarbon 51 337-360.

Brown, T.A., Nelson, D.E., Southon, J.R., 1988. Improved collagen extraction by modified Longin method. Radiocarbon 30, 171-177.

Carnieri, E., Mallegni, F., 2006. Le microusure dentarie di resti umani appartenent a Homo sapiens del Paleolitico Superiore italiano. In: Martini, F. (Ed.), La cultura del morire nelle società preistoriche e protostoriche italiane. Origines, Firenze pp. 293-303.

Cassoli, P.F., Tagliacozzo, A., 1982. La fauna della Grotta di Cala dei Genovesi a Levanzo. Rivista di Scienze Preistoriche 37, 48-58.

Cassoli, P.F., Tagliacozzo, A., 1997. Butchering and cooking of birds in the Palaeolithic site of Grotta Romanelli (Italy). International Journal of Osteoarchaeology 7, 303-320.

Chilardi, S., Frayer, D.W., Gioia, P., Macchiarelli, R., Mussi, M., 1996. Fontana Nuova di Ragusa (Sicily, Italy): southernmost Aurignacian site in Europe. Antiquity 70 553-563.

Colonese, A.C., Mannino, M.A., Bar-Yosef Mayer, D.E., Fa, D.A., Finlayson, J.C., Lubell, D., Stiner, M.C., 2011. Marine mollusc exploitation in Mediterranean prehistory: an overview. Quaternary International 239, 86-103.

Craig, O.E., Biazzo, M., Colonese, A.C., Di Giuseppe, Z., Martinez-Labarga, C., Lo Vetro, D., Lelli, R., Martini, F., Rickards, O., 2010. Stable isotope analysis of Late Upper Palaeolithic humans and fauna remains from Grotta del Romito (Cosenza), Italy. Journal of Archaeological Science 37, 2504-2512.

D’Amore, G., Di Marco, S., Tartarelli, G., Bigazzi, R., Sineo, L., 2009. Late Pleistocene human evolution in Sicily: comparative morphometric analysis of Grotta di San Teodoro craniofacial remains. Journal of Human Evolution 56, 537-550.

Durante, S., 1978. Note on Salmo trutta L. in the Pleistocene of Praia a Mare, (Southern Italy). Quaternaria 20, 117-121.

Fiore, I., Pino Uria, B., Tagliacozzo, A., 2004. L'exploitation des petits animaux au Paléolithique supérieur-Mésolithique en Italie: l'exemple de la Grotta del Santuario della Madonna de Praia a Mare (Cosenza, Italie). In: Brugal, J.-P., Desse, J. (Eds.), Petits Animaux et Sociétés Humaines. Du Complément Alimentaire aux Ressources Utilitaires. APDCA, Antibes, pp. 417-430.

Francalacci, P., 1988. Comparison of archaeological trace element and stable isotope data from two Italian coastal sites. Rivista di Antropologia 56, 239-250.

Garcia-Guixé, E., Subirà, M.E., Marlasca, R., Richards, M.P., 2010. $\delta^{13} \mathrm{C}$ and $\delta^{15} \mathrm{~N}$ in ancient and recent fish bones from the Mediterranean Sea. Journal of Nordic Archaeological Science 17, 83-92.

Graziosi, P., 1947. Gli uomini paleolitici della Grotta di S. Teodoro (Messina), (Antropologia). Rivista di Scienze Preistoriche 2, 123-329.

Hughes, P., Woodward, J., 2009. Glacial and periglacial environments. In: Woodward, J. (Ed.), The Physical Geography of the Mediterranean. Oxford University Press, Oxford, pp. 353-383.

Iacumin, P., Bocherens, H., Delgado Huertas, A., Mariotti, A., Longinelli, A., 1997. A stable isotope study of fossil mammal remains from the Paglicci cave Southern Italy. $\mathrm{N}$ and $\mathrm{C}$ as palaeoenvironmental indicators. Earth and Planetary Science Letters 148, 349-357.

Incarbona, A., Zarcone, G., Agate, M., Bonomo, S., Di Stefano, E., Masini, F., Russo, F., Sineo, L., 2010. A multidisciplinary approach to reveal the Sicily climate and environment over the last 20000 years. Central European Journal of Geosciences 2, 71-82.

Jennings, S., Reñones, O., Morales-Nin, B., Polunin, N.V.C., Moranta, J., Coll, J., 1997. Spatial variation in the ${ }^{15} \mathrm{~N}$ and ${ }^{13} \mathrm{C}$ stable isotope composition of plants, invertebrates and fishes on Mediterranean reefs: implications for the study of trophic pathways. Marine Ecology Progress Series 146, 109-116.

Lambeck, K., Antonioli, F., Purcell, A., Silenzi, S., 2004. Sea-level change along the Italian coast for the past 10,000 yr. Quaternary Science Reviews 23,1567-1598.

Lee-Thorp, J.A., 2008. On isotopes and old bones. Archaeometry 50, 925-950.

Lightfoot, E., Boneva, B., Miracle, P.T., Šlaus, M., O'Connell, T.C., 2011. Exploring the Mesolithic and Neolithic transition in Croatia through isotopic investigations. Antiquity $85,73-86$.

Macklin, M.G., Lewin, J., Woodward, J.C., 1995. Quaternary fluvial systems in the Mediterranean basin. In: Lewin, J., Macklin, M.G., Woodward, J.C. (Eds.), Mediterranean Quaternary River Environments. A.A. Balkema, Rotterdam, pp. 1-25

Mangano, G., 2005. I resti faunistici del Tardiglaciale della Grotta di S. Teodoro (Acquedolci, Messina). In: Fiore, I., Malerba, G., Chilardi, S. (Eds.), Atti del 3
Convegno Nazionale di Archeozoologia, Studi di Paletnologia II, Collana de Bullettino di Paletnologia. Istituto Poligrafico e Zecca dello Stato, Roma, pp. 173-180.

Mannino, M.A., Thomas, K.D., 2007. New radiocarbon dates for hunter-gatherers and early farmers in Sicily. Accordia Research Papers 10, 13-33.

Mannino, M.A., Thomas, K.D., 2009. Current research on prehistoric human coastal ecology: Late Pleistocene and Early Holocene hunter-gatherer transitions in north-west Sicily. In: McCartan, S., Schulting, R., Warren, G., Woodman, P. (Eds.) Mesolithic Horizons. Oxbow Books, Oxford, pp. 140-145.

Mannino, M.A., Thomas, K.D., 2010. Studio preliminare del campione faunistico della Grotta Schiacciata a Levanzo (Trapani). In: Tagliacozzo, A., Fiore, I., Marconi, S. Tecchiati, U. (Eds.), Atti del $5^{\circ}$ Convegno Nazionale di Archeozoologia, Rovereto, 10-12 novembre 2006. Edizioni Osiride, Rovereto, pp. 97-99.

Mannino, M.A., Thomas, K.D., Leng, M.J., Di Salvo, R., Richards, M.P. Stuck to the shore? Investigating prehistoric hunter-gatherer subsistence, mobility and territoriality in a Mediterranean coastal landscape through isotope analyses on marine mollusc shell carbonates and human bone collagen. Quaternary International, in press. doi:10.1016/j.quaint.2011.05.044.

Martini, F., Lo Vetro, D., Colonese, A.C., De Curtis, O., Di Giuseppe, Z., Locatelli, E., Sala, B., 2007. L'Epigravettiano Finale in Sicilia. In: Martini, F. (Ed.), L'Italia tra 15000 e 10000 anni fa. Cosmopolitismo e regionalità nel Tardoglaciale, Atti della Tavola rotonda, Firenze 18 novembre 2005. Museo Fiorentino di Preistoria, Firenze, pp. 209-253.

Maviglia, C., 1940. Scheletri umani del Paleolitico Superiore rinvenuti nella Grotta di S. Teodoro (Messina). Archivio per l'Antropologia e la Etnologia 70 94-104.

Persic, A., Roche, H., Ramade, F., 2004. Stable carbon and nitrogen isotope quantitative structural assessment of dominant species from the Vaccarès Lagoon trophic web (Camargue Biosphere Reserve, France). Estuarine, Coastal and Shel Science 60, 261-272.

Ravazzi, C., 2003. An overview of the Quaternary continental stratigraphic units based on biological and climatic events in Italy. Il Quaternario 16 (1 Bis), 11-18.

Reimer, P.J., Baillie, M.G.L., Bard, E., Bayliss, A., Beck, J.W., Blackwell, P.G., Bronk Ramsey, C., Buck, C.E., Burr, G.S., Edwards, R.L., Friedrich, M., Grootes, P.M. Guilderson, T.P., Hajdas, I., Heaton, T.J., Hogg, A.G., Hughen, K.A., Kaiser, K.F. Kromer, B., McCormac, F.G., Manning, S.W., Reimer, R.W., Richards, D.A Southon, J.R., Talamo, S., Turney, C.S.M., van der Plicht, J., Weyhenmeyer, C.E. 2009. INTCAL09 and MARINE09 radiocarbon age calibration curves, 0-50,000 years cal BP. Radiocarbon 51, 1111-1150.

Richards, M.P., Hedges, R.E.M., 1999. Stable isotope evidence for similarities in the types of marine foods used by late Mesolithic humans at sites along the Atlantic coast of Europe. Journal of Archaeological Science 26, 717-722.

Richards, M.P., Pettitt, P.B., Stiner, M.C., Trinkaus, E., 2001. Stable isotope evidence for increasing dietary breadth in the European mid-Upper Palaeolithic Proceedings of the National Academy of Sciences of the U.S.A. 98, $6528-6532$

Richards, M.P., Trinkaus, E., 2009. Isotopic evidence for the diets of European Neanderthals and early modern humans. Proceedings of the National Academy of Sciences of the U.S.A. 106, 16034-16039.

Russ, H., Jones, A.K.G., 2009. Late Upper Palaeolithic fishing in the Fucino Basin, central Italy, a detailed analysis of the remains from Grotta di Pozzo. Environmental Archaeology 14, 155-162.

Schoeninger, M.J., DeNiro, M.J., 1984. Nitrogen and carbon isotopic composition of bone collagen from marine and terrestrial animals. Geochimica et Cosmochimica Acta 48, 625-639.

Stiner, M.C., 2001. Thirty years on the "broad spectrum revolution" and Palaeolithic demography. Proceedings of the National Academy of Sciences of the U.S.A. 98 6993-6996.

Stiner, M.C., Munro, N.D., 2011. On the evolution of diet and landscape during the Upper Paleolithic through Mesolithic at Franchthi Cave (Peloponnese, Greece). Journal of Human Evolution 60, 618-636.

Tagliacozzo, A., 1993. Archeozoologia della Grotta dell'Uzzo, Sicilia. Da un'economia di caccia ad un'economia di pesca ed allevamento. Supplemento del Bullettino di Paletnologia Italiana 84. Poligrafico e Zecca dello Stato, Roma.

Tagliacozzo, A., 2003. Archeozoologia dei livelli dell'Epigravettiano Finale di Grotta Romanelli (Castro, Lecce). Strategie di caccia ed economia di sussistenza. In: Fabbri, P.F., Ingravallo, E., Mangia, A. (Eds.), Grotta Romanelli nel centenario della sua scoperta (1900-2000). Congedo Editore, Galatina (LE), pp. 169-216.

Tusa, S., 1999. La Sicilia nella preistoria, second ed. Sellerio editore, Palermo.

Tzedakis, P.C., 2009. Cenozoic climate and vegetation change. In: Woodward, J (Ed.), The Physical Geography of the Mediterranean. Oxford University Press, Oxford, pp. 89-137.

van Klinken, G.J., 1999. Bone collagen quality indicators for paleodietary and radiocarbon measurement. Journal of Archaeological Science 26, 687-695.

Vigliardi, A., 1968. L'industria litica della Grotta di San Teodoro in provincia di Messina (Scavi Graziosi-Maviglia). Rivista di Scienze Preistoriche 23, 33-144.

Wilkens, B. 1993. Lo sfruttamento delle risorse marine. In: Martini, F. (Ed.), Grotta della Serratura a Marina di Camerota. Culture e ambienti dei complessi olocenici. Garlatti e Razzai, Firenze, pp. 89-98.

Zuschin, M., Stachowitsch, M., Stanton Jr., R.J., 2003. Patterns and processes of shel ragmentation in modern and ancient marine environments. Earth-Science Reviews 63, 33-82. 